\title{
ANALISIS SISTEM PEMBELAJARAN TEMATIK SEKOLAH DASAR (STUDI KASUS PADA MIN TOWEREN KABUPATEN ACEH TENGAH)
}

\author{
Husna Gemasih ${ }^{1}$, Laili Wahyunita ${ }^{2}$ \\ ${ }^{\prime}$ Jurusan Teknik Informatika, Universitas Gadjah Putih, Indonesia \\ ${ }^{2}$ Jurusan Syariah, Institut Agama Islam Negeri Palangka Raya, Indonesia \\ laili.wahyunita@gmail.com
}

Naskah diterima: 15 Juli 2020, direvisi: 24 Mei, 2021, diterbitkan: 30 September, 2021

\begin{abstract}
The learning system is the most important role in education. MIN Toweren Aceh Tengah has a problem in the thematic learning system. Students have poor learning motivation in class. Analysis of the learning system at MIN Toweren was carried out to find its weaknesses. With the PISCES analysis method, the current performance of the learning system is the main source of problems. The results of the analysis are the basis for consideration for improvements in the learning system. The results of this study provide a solution for the development of a digital-based learning system in grade 1 mathematics thematic lessons at MIN Toweren. From the evaluation carried out on the implementation of this digital learning system, students are considered to be more motivated in learning.
\end{abstract}

Keywords: Digital learning system, MIN Toweren, PISCES.

\section{ABSTRAK}

Sistem pembelajaran adalah peran terpenting dalam pendidikan. MIN Toweren Aceh Tengah memiliki masalah dalam sistem pembelajaran tematik. Siswa memiliki motivasi belajar yang buruk di kelas. Analisis sistem pembelajaran di MIN Toweren dilakukan untuk menemukan kelemahannya. Dengan metode analisis PISCES, kinerja sistem pembelajaran saat ini sebagai sumber masalah utama. Hasil analisis merupakan dasar pertimbangan untuk dilakukan perbaikan dalam sistem pembelajaran. Hasil penelitian ini memberikan solusi untuk pengembangan sistem pembelajaran berbasis digital pada pelajaran tematik matematika kelas 1 di MIN Toweren. Dari evaluasi yang dilakukan terhadap implementasi sistem pembelajaran digital ini, siswa dinilai lebih termotivasi dalam belajar.

Kata Kunci: Sistem pembelajaran digital, MIN Toweren, PISCES

\section{Pendahuluan}

Tujuan pendidikan dasar adalah meletakkan dasar kecerdasan, pengetahuan, kepribadian akhlak mulia, serta keterampilan untuk hidup mandiri dan mengikuti pendidikan lebih lanjut. Merujuk pada tujuan pendidikan dasar tesebut, maka tujuan sekolah MIN Toweren adalah dapat mengamalkan ajaran agama hasil proses pembelajaran, meraih prestasi akademik maupun non-akademik minimal tingkat kabupaten/ kota, menguasai dasar-dasar ilmu pengetahuan dan teknologi sebagai bekal untuk melanjutkan ke sekolah yang lebih tinggi, menjadi sekolah pelopor dan penggerak di lingkungan masyarakat sekitar serta menjadi sekolah yang diminati masyarakat (Prananda, Wardana, and ... 2021). 
Madrasah Ibtidaiyah Negeri (MIN) Toweren merupakan salah satu Madrasah Ibtidayah yang berada di Kabupaten Aceh Tengah yang beralamat di Jln. Takengon-Bintang Kampung Toweren Toa Kecamatan Lut Tawar Kabupaten Aceh Tengah. Sekolah ini didirikan oleh Tokoh Ulama dan Masyarakat pada tahun 1940 dengan nama awalnya adalah SRI (Sekolah Rendah Islam). Pada tahun 1949 SRI berganti nama menjadi MIN Toweren dan pada tahun tersebut dinegerikan oleh Pemerintah sampai saat ini (L n.d.).

Sistem pembelajaran yang ada pada MIN Toweren sama dengan sekolah lain, yaitu masuk jam 7.30 WIB dan pulang jam 13.10 WIB dan hari efektif mengikuti kalender pendidikan yang dikeluarkan oleh pemerintah kemudian proses belajar mengajar menggunakan kurikulum KTSP 2006 Berkarakter (L n.d.).

Pada MIN Toweren untuk kelas 1 guru mengajar dengan menggunakan Pembelajaran Tematik, yaitu metode pembelajaran yang memadukan satu pokok bahasan ditinjau dari berbagai disiplin ilmu yang memiliki keterkaitan satu sama lain dan dikemas dalam bentuk tema-tema. Dengan pembelajaran terpadu tersebut, guru berperan memadukan dan menyatukan pemahaman/wawasan siswa terhadap sejumlah materi tanpa terkotak-kotak dengan label bidang studi tertentu. Dengan meminimalkan pengotakan antar bidang studi, yaitu pengetahuan, sikap, dan keterampilan yang diperoleh dari berbagai bidang studi, tidak perlu dikemas dalam paket-paket yang saling terpisah.

Guru melakukan pembelajaran tersebut dengan menggunakan media papan tulis dan buku dalam pembelajaran, sehingga kurang menarik dan tidak meningkatkan minat siswa dalam mempelajari materi tersebut. Metode ini membuat guru harus bekerja lebih keras untuk memberikan materi pelajaran, apalagi terdapatnya beberapa siswa kelas 1 yang tidak dapat membaca. Pada penelitian terdahulu dikemukakan bahwa penggunaan buku sebagai media pembelajaran kurang efektif dalam menarik antisiasme siswa (Prananda et al. 2021) Pemilihan media pembelajaran sangat berpengaruh dalam kesuksesan pencapaian tujuan pembelajaran.

Dunia teknologi digital yang semakin berkembang juga membawa perubahan yang besar pada pendidikan (Rahardja et al. 2019). Selain itu, anak-anak zaman sekarang sudah mudah dan cepat memahami penggunaan media digital (Sardiana 2021). Penelitian pengembangan media pembelajaran berbasis elektronik dan multimedia mulai banyak dikembangankan. Pengembangan media ajar berbasis elektronik dengan produk e-module dinilai telah efektif dalam meningkatkan pemahaman siswa (Wijayanti et al. 2021). Pembuatan bahan ajar berbasis multimedia dengan menggunakan macromedia flash 8 menghasilkan peningkatan nilai hasil belajar (Nurhasanah 2021). Untuk menentukan pembuatan media ajar yang tepat harus dilakukan analisis sistem terlebih dahulu. Kondisi siswa dan lingkungan sekolah menjadi pertimbangan yang penting dalam menganilisis sistem yang akan dikembangkan.

Analisis sistem pembelajaran pada MIN Toweren ini dilakukan untuk mengetahui kelemahan sistem yang sudah berjalan saat ini. Hasil analisis sistem dari penelitian ini dijadikan referensi dalam merancang kebutuhan sistem pembelajaran yang lebih baik. Penelitian ini menghasilkan rancangan sistem pembelajaran digital pada pelajaran tematik matematika kelas 1 .

\section{Metodologi}

Penelitian ini merupakan penelitian lapangan dengan mengambil studi kasus pada MIN Toweren Kabupaten Aceh Tengah. Metode pencarian data dilakukan melalui pengamatan langsung di lapangan, dengan cara pengumpulan data dengan mempelajari suatu sistem pembelajaran tematik yang sedang berjalan. Studi litetatur mencakup metode 
pencarian data dari buku, browsing internet atau literatur-literatur lain juga dilakukan untuk menganalisis hasil data lapangan yang diperoleh.

Penelitian ini menggunakan model prototype dalam pengembangan sistem. Hasil data lapangan yang diperoleh untuk analisis sistem yang tengah berjalan digunakan sebagai aspek-aspek yang dibutuhkan dalam sistem yang akan dikembangkan. Model prototype menyajikan fungsi-fungsi perangkat lunak yang akan dievaluasi oleh pengguna untuk menyaring kebutuhan pengembangan perangkat lunak (Pricillia and Zulfachmi 2021). Gambar 1 menunjukkan visualisasi metodologi pada penelitian ini.

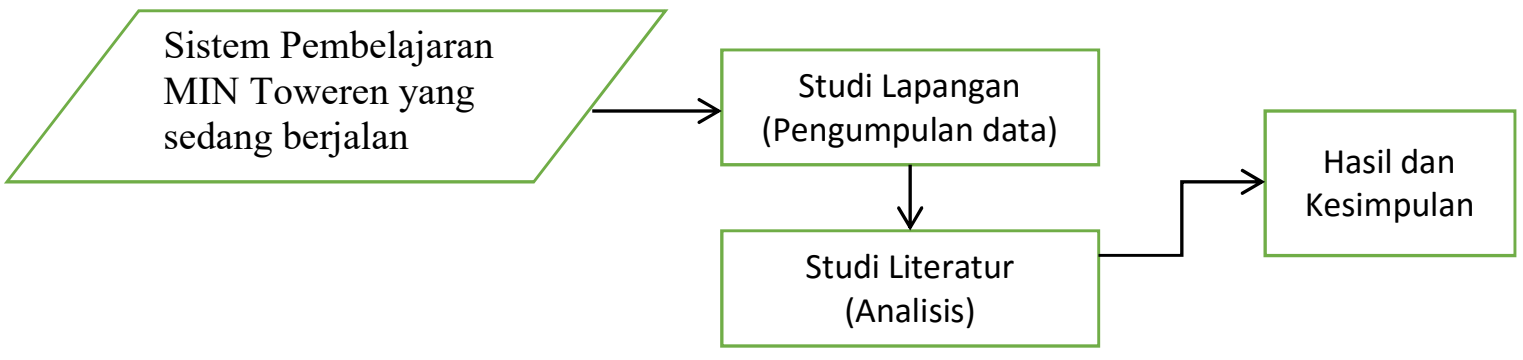

Gambar 1. Ilustrasi Metodologi Penelitian

\section{Hasil dan Diskusi}

Pembelajaran yang dilaksanakan seorang pendidik, pada dasarnya adalah sebuah sistem, karena pembelajaran adalah suatu kegiatan yang bertujuan untuk mendidik peserta didik. Proses pembelajaran merupakan rangkaian kegiatan yang melibatkan berbagai komponen. Hal itu perlu dipahami, karena melalui pemahaman terhadap sistem pembelajaran, minimal guru akan memahami tentang tujuan pembelajaran atau hasil yang diharapkan, proses kegiatan pembelajaran yang harus dilakukan, pemanfaatan setiap komponen dalam proses kegiatan untuk mencapai tujuan yang ingin dicapai dan bagaimana mengetahui keberhasilan pencapaian tersebut. Pemahaman terhadap sistem juga bermanfaat untuk merancang atau merencanakan suatu proses pembelajaran.

Sistem yang sedang berjalan di MIN Toweren masih manual, pembelajaran dilakukan dengan menggunakan media papan tulis blackboard dan kapur tulis, akibatnya tampilanya kurang menarik perhatian siswa. didalam kelas tidak semua siswa dapat secara cepat menangkap dalam menerima materi pelajaran yang diberikan oleh guru yang mengakibatkan guru harus bekerja keras dalam menyampaikan materi pelajaran agar materi tersebut sampai kepada semua siswa tersebut.

Agar proses belajar berjalan sesuai harapan dan guru tidak harus ekstra keras hanya dalam mengajarkan satu materi namun semua siswa dapat menerima materi pelajaran secara bersama-sama tanpa ada yang tertinggal dan proses belajar mengajar menjadi lebih efektif dan efesien, maka perlu dibuat sebuah sistem pembelajaran digital yang menampilkan materi pelajaran dengan tampilan yang sangat menarik dan menampilkan soal-soal latihan dari materi yang telah diberikan.

\subsection{Hasil Analisis Kelemahan Sistem Pembelajaran}

Pada sistem pembelajaran yang sedang berjalan merupakan sistem yang manual dan belum terkomputerisasi, sistem tersebut tidak efektif dan efisiennya pemberian meteri sehingga pelayanan jasa guru menjadi sedikit menurun (Fatta 2007). Untuk mengidentifikasi masalah tersebut dapat digunakan sebuah panduan untuk menganalisis kinerja, informasi, 
ekonomi, keamanan, efesiensi serta pelayanan. Panduan ini disebut dengan PIECES (Performance, Informastion, Economy, Control, Eficiency, dan Services).

1. Analisis Kinerja (Performance)

Kelemahan sistem yang lama harus membutuhkan tenaga eksra untuk memberikan meteri pelajaran kepada siswa karena tidak semua siswa mempunyai daya tanggap yanga sama, serta guru harus mengulangi penjelasan kepada siswa yang kurang tanggap dan itu membuat siswa yang cepat tanggap menjadi bosan sehingga hal tersebut membutuhkan waktu yang lama hanya untuk satu materi pelajaran saja.

2. Analisis Informasi (Information)

Informasi yang didapat siswa tidak sesuai harapan karena sistem pembelajaran akan terhenti jika guru tersebut berhalangan hadir, jika pun ada guru pengganti materi yang diberikan tidak akan sama dengan guru sebelumnya karena guru pengganti tersebut tidak ahli dibidang tersebut.

3. Analisis Ekonomi (Economy)

Untuk membuat materi yang menarik harus mengeluarkan biaya tambahan.

4. Analisis Keamanan (Control)

Tidak tersedianya back up data. sekolah hanya menggunakan buku panduan, jika

buku panduan hilang atau rusak maka sistem pembelajaran akan menjadi terganggu.

5. Analisis Efisiensi (Eficiency)

Waktu penyampaian materi tidak efisien karena guru dalam penyampaian meteri cenderung tergesa-gesa dan harus sering mengulang kembali materi sehingga tidak efisien dan efektif.

6. Analisis Layanan (Services)

Pelayanan tidak memuaskan karena akibat lambatnya kinerja guru serta tidak efektifnya pemberian meteri sehingga pelayanan jasa guru menjadi sedikit menurun.

\subsection{Hasil Pengembangan Sistem Pembelajaran Digital}

Latihan soal berbasis digital dapat dilihat pada Gambar 2. Latihan soal. Disediakan 20 soal yang mana jika ingin ke menu latihan maka klik file - latihan. Nomor yang ada dikotak adalah nomor soal. Setiap kotak mewakili satu soal. Contoh salah satu soal dari 20 soal ditunjukkan pada Gambar 3. Kemudian untuk menjawab soal maka klik titik-titik. Maka titik-titik akan hilang dan gambar awan muncul, ketik jawaban lalu klik awan uuntuk mengecek jawaban benar atau salah. Jika jawaban salah maka muncul tanda silang

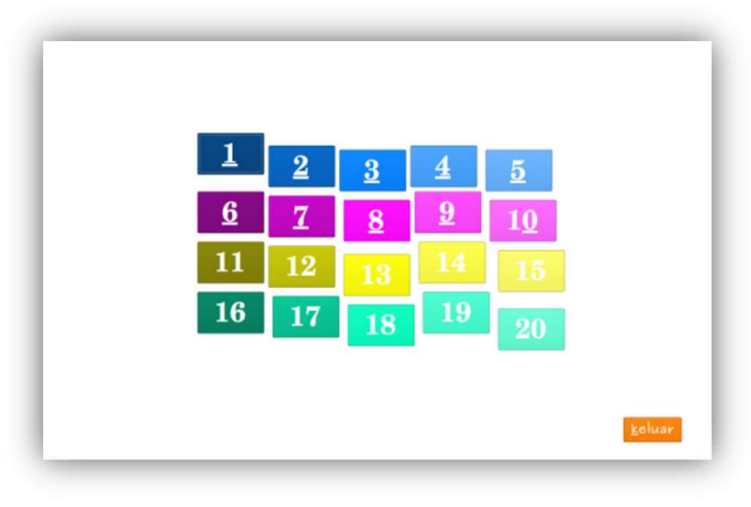

Gambar 2. Latihan soal 


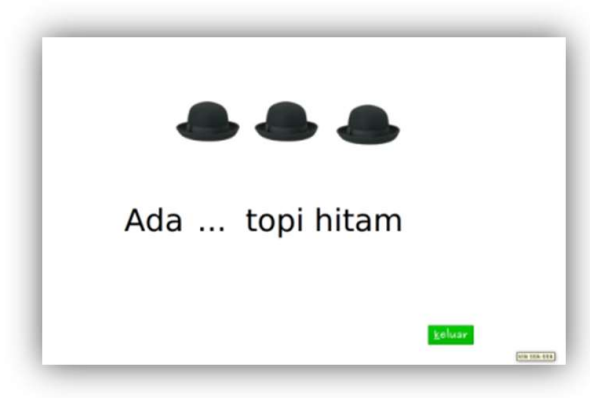

\section{Gambar 3. Contoh soal latihan}

Jika ingin mengulangi lagi maka klik tanda silang yang muncul. Kemudian pilih keluar jika ingin kembali ke menu soal. jika ingin melanjutkan ke soal yang lain klik kotak yang diinginkan

\subsection{Materi Penggunaan Simbol Operasi Matematika}

Materi penggunaan simbol terdiri dari penjelasan penggunaan simbol angka dan tanda,,$+-=$, serta latihan bilangan dalam menempatkan simbol tersebut. Kemudian setelah tampilan muncul klik buah dan kalimat satu persatu dari baris pertama sampai ketiga dari kiri kekanan lakukan seperti perintah berkedip yang muncul sampai buah terakhir maka penjelasan materi tersebut telah selesai. Pada Gambar 4 diperlihatkan bagaimana soal digital pada operasi bilangan dengan menggunakan symbol.

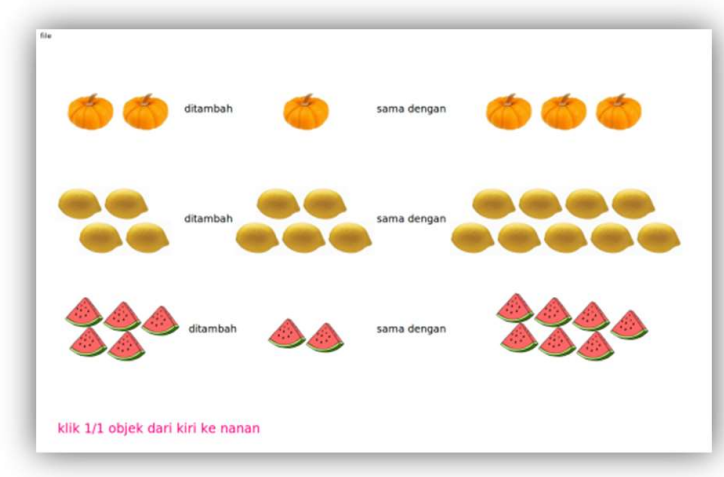

\section{Gambar 4. Latihan operasi tanpa simbol}

\subsection{Materi Sifat Operasi Hitung}

Materi sifat operasi hitung terdiri dari penjelasan mengenai sifat penjumlahan serta latihan. Tampilan tersebut klik buah perkelompok dari kiri kekanan, dari atas kebawah lakukan tindakan seperti perintah petunjuk berkedip-kedip yang muncul satu persatu. Penjelasan selesai jika tampilan ditunjukkan pada Gambar 5. 


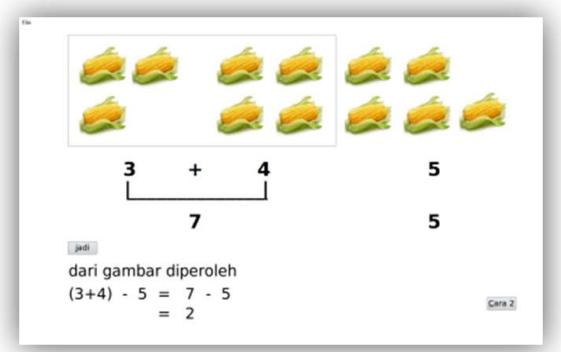

\section{Gambar 5. Operasi hitung}

\subsection{Penyelesaian Masalah Penjumlahan}

Materi penyelesaian masalah penjumlahan terdiri dari penjelasan mengenai cara penyelesaian masalah penjumlahan serta latihan. Pada bagian sudut kiri atas terdapat menu file yang terdiri dari ulang, latihan dan keluar. Ulang berarti kembali pada tampilan seperti diatas, latihan uuntuk membuka tampilan latihan, keluar kembali ke menu utama. Ketika kata mulai diklik maka akan muncul tampilan penjumlahan bagian pertama yang diperlihatkan pada Gambar 6.

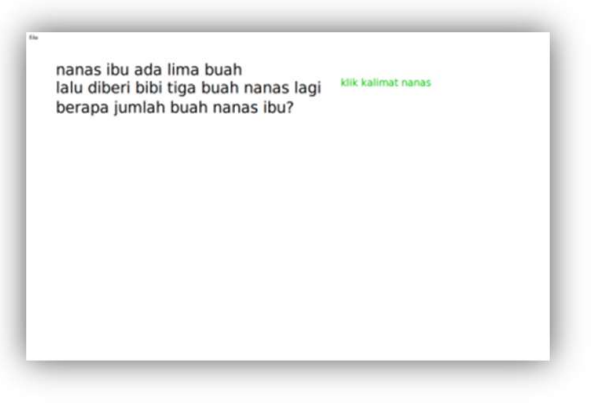

\section{Gambar 6. Tampilan penjelasan soal penjumlahan}

Setelah muncul tampilan tersebut lakukan tindakan seperti perintah petunjuk berkedip-kedip yang muncul satu persatu. jika telah selesai berhitung maka ketikkan jumlah buah di titik-titik. Penjelasan selesai jika tampilan sudah seperti Gambar 7.

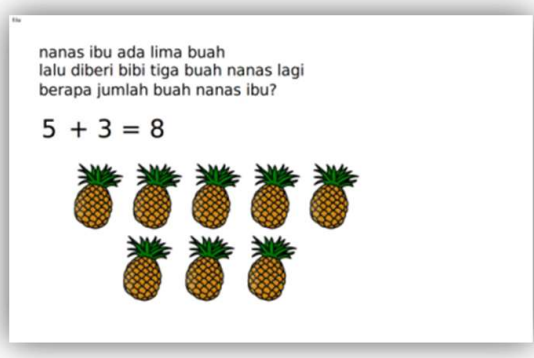

\section{Gambar 7. Hasil Penyelesaian soal penjumlahan}


Jika ingin mengulang penjelasan maka klik file - ulang di sudut kiri atas lalu klik mulai, maka penjelasan seperti Gambar 7 akan muncul kembali. Jika ingin ke menu latihan maka klik file - latihan. Tampilan yang akan muncul adalah seperti Gambar 8 .

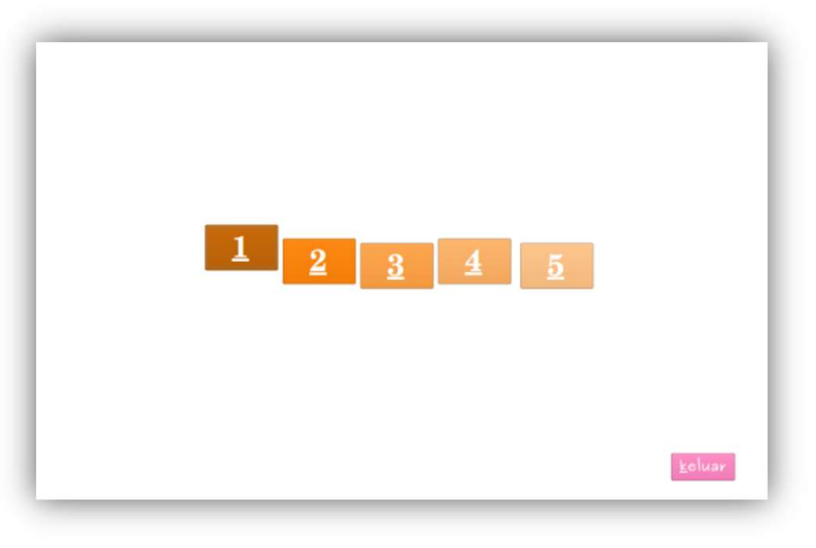

Gambar 8. Tampilan menu latihan soal penjumlahan

Nomor yang ada dikotak adalah nomor soal, jumlah soal yang disediakan ada 5 soal. Setiap kotak mewakili satu soal. Klik keluar jika ingin kembali ke menu tama. Tampilan yang muncul setelah kotak 1 diklik adalah seperti Gambar 9.

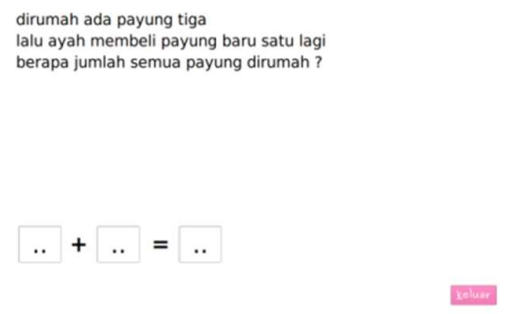

\section{Gambar 9. Contoh soal penjumlahan}

Jika tampilan seperti diatas telah muncul, maka klik kalimat pertama lalu klik kalimat kedua kemudian ketik jawaban kedalam kotak. Ketika kotak hasil penjumlahan diklik maka akan muncul cek, klik cek uuntuk mengecek jawaban benar atau salah. Jika jawaban salah maka akan muncul tanda silang, seperti Gambar 10. Jika jawaban benar maka akan muncul tanda ceklis, seperti Gambar 11. 


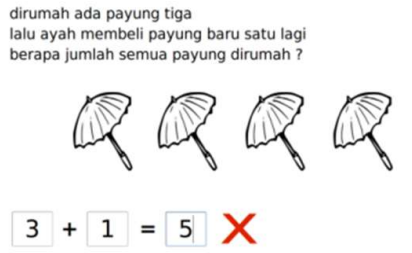

Gambar 10. Contoh jawaban yang salah

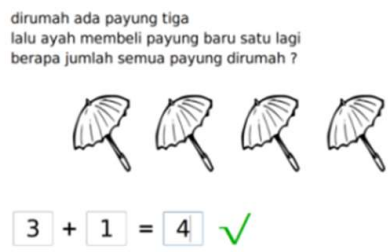

\section{Gambar 11. Contoh jawaban yang benar}

\subsection{Penyelesaian Masalah Pengurangan}

Materi penyelesaian masalah pengurangan terdiri dari penjelasan mengenai cara penyelesaian masalah pengurangan serta latihan. Pada bagian sudut kiri atas terdapat menu file yang terdiri dari ulang, latihan dan keluar. Ulang berarti kembali pada tampilan seperti diatas, latihan uuntuk membuka tampilan latihan, keluar kembali ke menu utama. Ketika kata mulai diklik maka akan muncul tampilan penjumlahan bagian pertama seperti Gambar 12.

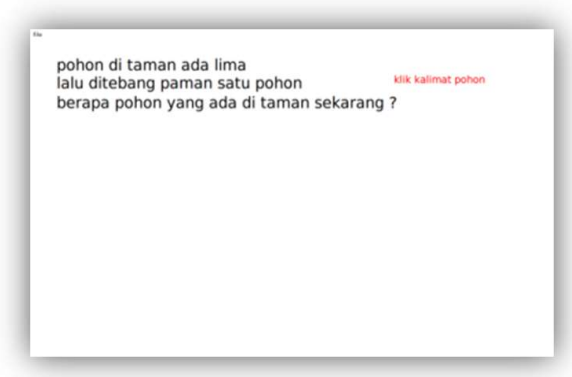

\section{Gambar 12. Tampilan penjelasan operasi pengurangan}

Setelah muncul tampilan tersebut lakukan tindakan seperti perintah petunjuk berkedip-kedip yang muncul satu persatu. jika telah selesai berhitung maka ketikkan jumlah pohon di titik-titik. Penjelasan selesai jika tampilan sudah seperti Gambar 13. 


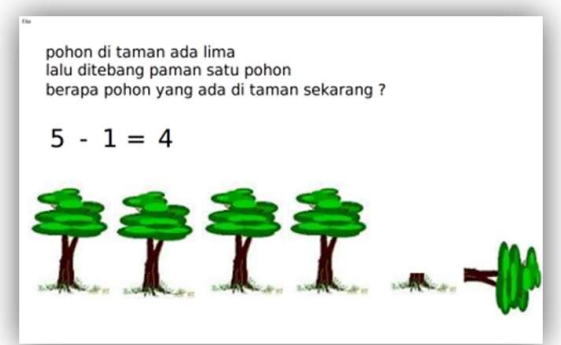

\section{Gambar 13. Penyelesaian soal pengurangan}

Jika ingin mengulang penjelasan maka klik file - ulang di sudut kiri atas lalu klik mulai, maka penjelasan seperti Gambar 12 akan muncul kembali. Jika ingin ke menu latihan maka klik file - latihan. Tampilan yang akan muncul adalah seperti Gambar 14.

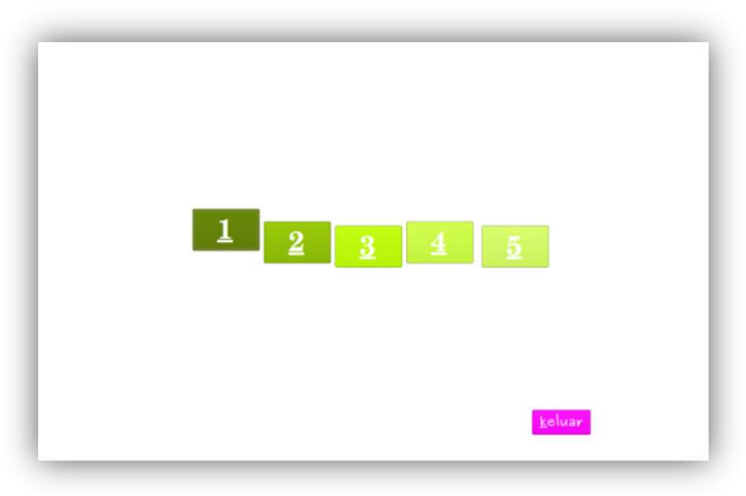

\section{Gambar 14. Tampilan menu soal latihan pengurangan}

Nomor yang ada dikotak adalah nomor soal, jumlah soal yang disediakan ada 5 soal. Setiap kotak mewakili satu soal. Klik keluar jika ingin kembali ke menu tama. Tampilan yang muncul setelah kotak 1 diklik adalah seperti Gambar 15.

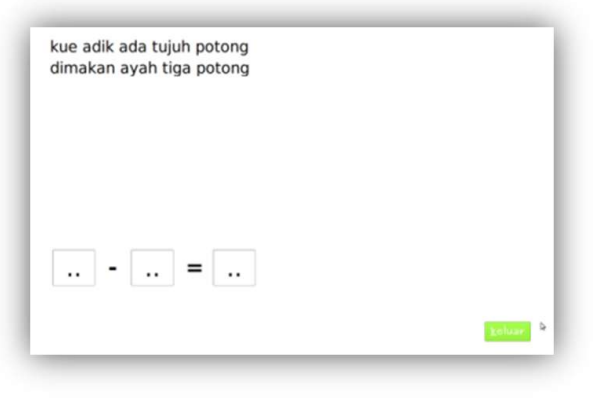

\section{Gambar 15. Contoh soal latihan pengurangan}

Jika tampilan seperti diatas telah muncul, maka klik kalimat pertama lalu klik kalimat kedua kemudian ketik jawaban kedalam kotak. Ketika kotak hasil penjumlahan 
diklik maka akan muncul cek, klik cek uuntuk mengecek jawaban benar atau salah. Jika jawaban salah maka akan muncul tanda silang, seperti Gambar 16. Jika jawaban benar maka akan muncul tanda ceklis, seperti Gambar 17.

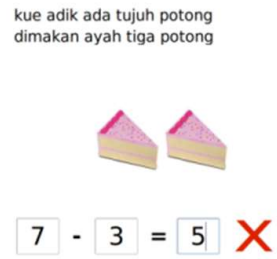

Gambar 16. Contoh tampilan jika jawaban salah

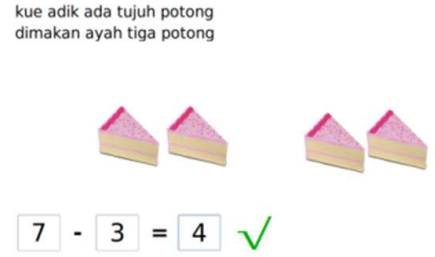

Gambar 17. Contoh tampilan jika jawaban benar

\section{Kesimpulan}

Sistem pembelajaran yang sedang berjalan di MIN Toweren masih manual ditambah lagi dengan kurangnya buku panduan untuk para siswa yang mengakibatkan kurangnya minat siswa dalam belajar serta guru harus memberikan tenaga ekstra dalam memberikan materi pelajaran. Hasil analisis kekurangan sistem peneliti dapat memberikan saran untuk dapat melibatkan teknologi komputer dalam memberikan pembelajaran kepada siswa dengan membuat tampilan-tampilan yang menarik perhatian siswa, tidak hanya monoton kepada papan tulis dan buku panduan saja. Diharapkan untuk meningkatkan kreatifitas dalam mengajar, sehingga dapat membuat bermacam-macam materi pembelajaran yang sudah terkomputerisasi dengan tampilan menarik yang akan meningkatkan minat siswa.

\section{Daftar Pustaka}

Fatta, Hanif Al. 2007. Analisis Dan Perancangan Sistem Informasi. Yogyakarta: Andi.

L, H. dan. n.d. Observasi.

Nurhasanah, Enung. 2021. "Pengembangan Multimedia Pembelajaran Sejarah

Perkembangan Islam Berbasis Macromedia Flash Untuk Meningkatkan Hasil Belajar Mahasiswa." 2:148-53.

Prananda, G., A. Wardana, and ... 2021. "Pengembangan Media Video Pembelajaran Tema 6 Subtema 2 Untuk Siswa Kelas SD Negeri 17 Pasar Masurai 1.” Jurnal Dharma 
PGSD 1.

Pricillia, Titania, and Zulfachmi. 2021. "Perbandingan Metode Pengembangan Perangkat Lunak." Survey Paper X(01):6-12.

Rahardja, Untung, Ninda Lutfiani, Eka Purnama Harahap, and Lidya Wijayanti. 2019. "ILearning: Metode Pembelajaran Inovatif Di Era Education 4.0." Technomedia Journal 4(2):261-76. doi: 10.33050/tmj.v4i2.1010.

Sardiana, Anna. 2021. "Devices Impact on the Childern: A Swot Analysis 1." Al-Aulad: Journal of Islamic Primary Education 4(1):25-34.

Wijayanti, Kiki, Muhammad Abdul Ghofur, Economic Education Program, and Universitas Negeri Surabaya. 2021. "Pengembangan Media Pembelajaran E-Modul Bank Dan Sistem Pembayaran Berbasis Android Untuk Peserta Didik Kelas X." 14(1):1-14. 